\title{
Crime e violências em São Paulo: retrospectiva teórico-metodológica, avanços, limites e perspectivas futuras
}

\author{
Crime and violences in São Paulo: theoretical-methodological \\ retrospective, advances, limits and future perspectives
}

Sérgio Adorno [l] Marcelo Batista Nery [II]

\section{Resumo}

Este artigo trata da análise das relações entre crime, violência e cidades, um objeto tradicional das ciências sociais e dos estudos urbanos. Tendo a cidade de São Paulo como pano de fundo e os homicídios dolosos como parâmetro, procura-se registrar a evolução dos registros vitais e criminais e questionar a hipótese que analisa e explica a distribuição dos crimes, nos territórios urbanos, baseada na lógica dualista e binária entre bairros não- violentos e violentos, entre centro e periferia. Avaliando o estoque de conhecimento disponível nesste campo de estudos, e discutindo questões metodológicas relativas à qualidade dos dados que sustentam análises, o artigo propõem algumas abordagens metodológicas que hoje podem melhor explicar a distribuição dos crimes em um tecido metropolitano diversificado e complexo.

Palavras-chave: crime; violência; homicídios; cidades; São Paulo capital.

\begin{abstract}
This article analyzes the relationships between crime, violence and cities, a traditional object of the social sciences and urban studies. With the city of São Paulo as the background and reported murders as the parameter, the article registers the evolution of vital and criminal records and questions the hypothesis that analyzes and explains crime distribution, in urban territories, based on the dualistic and binary logic between non-violent and violent neighborhoods, between center and periphery. Evaluating the stock of knowledge available in this field of study and discussing methodological issues related to the quality of the data that support analyses, the article proposes some methodological approaches that, today, can better explain crime distribution in a diversified and complex metropolitan fabric.
\end{abstract}

Keywords: crime; violence; homicides; cities; city of São Paulo. 
Não são recentes as preocupações e os estudos que se ocupam das relações entre cidades, violências e crime. Desde o último quartel do século XVIII, muitos estudiosos, historiadores, periodistas, escritores e toda sorte de moralistas já procuravam estabelecer, seja com entusiasmo seja com nostalgia, conexões entre industrialização, urbanização e transformações nos costumes, nas relações hierárquicas, nos usos e nas ocupações das cidades. Para não poucos, a marcha dessas mudanças estava na raiz do caos social que parecia dominar as grandes capitais europeias, representado, sobretudo, pela existência de vastos contingentes de pobres, desempregados, prostitutas, crianças abandonadas, homens ébrios largados ao chão, andrajosos de toda espécie, muitos dos quais vagando sem destino definido pelas ruas de grande circulação (Linebaugh, 1983; Tobias, 1967; Mucchielli, 1998). No final do século XIX e início do século $X X$, essas mesmas preocupações também estiverem presentes nos Estados Unidos, em virtude do rápido crescimento dos crimes em geral e em especial dos homicídios decorrentes dos conflitos entre gangues e a polícia, a difusão de armas de fogo, a elevação das taxas de encarceramento, fonte de rebeliões e protestos (Gurr, 1989).

No Brasil, estudos históricos igualmente demonstram que essas inquietações não são recentes, ainda que a produção bibliográfica seja modesta quando comparada com as tradições europeias e norte-americanas. Ao menos, desde meados do século XIX, o medo do crime como expressão das mudanças urbanas já se fazia observar no noticiário da imprensa local, como demonstrado no pioneiro estudo de Fausto (1984). Tanto lá, como cá, buscou-se estabelecer possíveis relações de causalidade entre transformações econômico-sociais, sobretudo urbanas, e a evolução da violência e do crime. Os modelos explicativos variam, contemplando desde forças relacionadas à dinâmica social, à mudança das instituições, inclusive de controle social e legal, até a mudança de valores de uma sociedade tradicional na direção de sua modernização.

No último quartel do século $X X$, justamente quando se desencadeou, na sociedade brasileira, a transição da ditadura-militar para o regime democrático, esperava-se que o fim de todas as arbitrariedades e perseguições contra a dissidência política resultasse na pacificação geral da sociedade. Não foi o que aconteceu. A transição foi acompanhada da explosão de, ao menos, quatro modalidades de violências e crimes: o crescimento da delinquência comum em torno dos crimes contra o patrimônio; 0 crescimento dos homicídios, associados ou não à chegada, na sociedade brasileira, do chamado crime organizado em torno principalmente do tráfico de drogas; graves violações de direitos humanos, representadas, sobretudo, por violência policial ou de agentes públicos nas delegacias de polícia, prisões e instituições de tutela de crianças e adolescentes; explosão de conflitos, com desfechos fatais, nas relações interpessoais e intersubjetivas nas famílias, nas escolas, nos bairros, nas ruas, nos ambientes de trabalho. Mais recentemente, esse quadro foi agravado com o controle de amplas massas carcerárias pelo crime organizado, com a difusão dos crimes cibernéticos e com conflitos envolvendo racismo, misoginia e homofobia que, não raro, levam a desfechos fatais.

Nesse cenário de percepções sociais agudas de insegurança coletiva, as cidades foram mudando de fisionomia e em suas 
configurações. Bairros cada vez mais segregados, sistemas de segurança privada por todos os espaços, câmaras fiscalizando o movimento das ruas, rumores sobre acontecimentos cotidianos, recomendações de como evitar ser vítima de crimes, relacionadas à circulação nas vias públicas, aos horários, à movimentação de pessoas, ao transporte público e mesmo privado, à proteção de pertences pessoais, ao contato com estranhos ou com comércio e serviços, onde morar e trabalhar, como desfrutar do lazer no final da semana e como proteger e fiscalizar filhos, especialmente infantes e adolescentes.

Neste artigo, não se pretende avaliar a vasta literatura que vem sendo produzida há quatro décadas, para as quais já foram feitas ao menos 5 revisões bibliográficas. 0 foco reside na distribuição dos crimes sobre os territórios urbanos, buscando identificar os argumentos frequentemente empregados para explicar seus possíveis nexos e correlações, inclusive possíveis relações de causalidade. Baseando em investigações realizadas e em andamento no Núcleo de Estudos da Violência da USP (nevusp. org), procura-se problematizar a hipótese corrente no debate: a da cidade partida; qual seja, a que congrega bairros seguros e bairros inseguros. Os homicídios estariam reunidos nos bairros com grande concentração de população de baixa renda e com precária infraestrutura urbana. Embora essa perspectiva venha sendo contestada, quando menos pela força dos dados - até porque a tese centro-periferia já, de longa data, é contestada nos estudos urbanos em geral -, o que se coloca neste artigo é o caminho metodológico capaz de melhor explicar como se dá a distribuição dos homicídios em um tecido urbano tão diversificado e complexo como o da cidade de São Paulo, capital deste estado da federação.

Neste artigo, não cuidaremos de todas as modalidades de crimes, porém de uma que, a par de sua centralidade nas inquietações coletivas, tem sido objeto de intervenções públicas. Trata-se dos homicídios. Nosso recorte geográfico será o estado de São Paulo, com destaque para o município da capital, no período compreendido de 1970 a 2016.

0 artigo está dividido da seguinte maneira: inicialmente, são apresentadas algumas considerações de ordem conceitual e metodológica. Segue-se uma descrição das tendências verificadas no período focalizado, destacando-se suas características e singularidades. Depois, uma terceira parte aborda a questão principal o homicídio sob a perspectiva intraurbana e uma conclusão procura reforçar os principais argumentos desenvolvidos e apontar linhas futuras de pesquisa decorrentes.

\section{Considerações conceituais e metodológicas}

Embora não seja aqui o espaço para maiores desenvolvimentos, é preciso desde já anunciar o que estamos compreendendo por violência: "fatos e ações humanas que se opõem, questionam ou perturbam a paz ou a ordem reconhecida como legítima. Seu uso corrente compreende o emprego de força brutal, desmedida, que não respeita limites ou regras convencionadas". Distingue-se do crime, "violência codificada nas leis penais" (Adorno, 2012, p. 72). Violência tem sentido polissêmico, pois depende dos valores considerados 
"sagrados" em uma sociedade em momento determinado de sua história. Sob essa perspectiva, "atos violentos estão referidos ao mundo das percepções coletivas e das representações" (ibid., p. 73). No mesmo sentido, suas formas e modalidades variam no tempo e no espaço. Em nossa sociedade, a violência está associada tanto às ofensas à integridade física ou ao patrimônio pessoal de quem quer que seja, quanto às agressões aos valores que sustêm identidades, sociais e subjetivas, e às graves ameaças aos direitos humanos consagrados na Constituição e nas convenções de que o País é signatário nesse campo.

Em termos sociológicos, a compreensão dos fatos violentos requer considerar contextos histórico-sociais nos quais ocorrem com maior frequência; os atores envolvidos, tanto protagonistas diretos ou indiretos - agressores e suas vítimas, testemunhas e autoridades encarregadas de apurá-los -; como, ainda, os meios e modos empregados nos desfechos violentos. Como apontam vários estudos, as condições sociais de vida predominantes nas metrópoles brasileiras e mesmo até nas cidades médias têm criado situações favoráveis para o crescimento e a expansão de violências e crimes, em especial aqueles que envolvem o direito fundamental à vida. Neste artigo, procura-se tecer comentários a respeito das complexas relações entre tecido urbano, modos de vida e desfechos fatais na resolução de conflitos em relações sociais e interpessoais.

De fato, a crescente urbanização do País tornou a sociedade brasileira mais complexa e mais conflituosa. A complexidade é percebida nas relações pessoais e intersubjetivas assim como também nas relações sociais e institucionais. Conflitos de diferentes espécies, não raro associados ao agravamento das desigualdades sociais, podem eventualmente tanto repercutir em desfechos violentos quanto estimular diferentes modalidades de violência e crime. Se, por um lado, o avanço das taxas de crimes é matéria pouco controversa, por outro, não ocorre o mesmo quando se busca generalizar relações diretas e imediatas entre contextos urbanos, nos quais predominam desigualdades sociais, e a evolução do crime.

Ainda que essas taxas apresentem uma tendência de aumento desde os anos 1950, declínios também são observados, e a variação intensifica-se à medida que se diminui a escala de análise - estados, áreas metropolitanas, cidades, unidades territoriais intraurbanas, etc. -, o que tem levado à elaboração de vários estudos urbanos sobre a variação dessas taxas. Nesses estudos, alguns dos fatores se mostram frequentemente relacionados aos crimes, enquanto outros apresentam comportamento mais instável, o que torna a criminalidade per se um fenômeno de difícil mensuração e compreensão.

No contexto brasileiro, esse desafio analítico é ainda mais marcante. Aqui não existem dados nacionais de crime, delinquência e suas derivações comparáveis entre e intraestados. Os dados nacionais disponíveis, sensíveis a esses graves problemas sociais e de segurança, aferem apenas as ocorrências de mortalidade por causas externas, como os homicídios, ou melhor, mortes por agressão que incluem homicídio. Constata-se que esses dados não estão baseados nos registros dos agentes de segurança pública, de homicídios ${ }^{1}$ ou de pessoas mortas em confronto com a polícia por exemplo, $^{2}$ mas naqueles extraídos dos registros oficiais dos agentes de saúde, tomando por base 0 
número de óbitos tipificados pela Classificação Internacional de Doenças como eventos decorrentes de agressões ou de intervenção legal. ${ }^{3}$

Outra circunstância que marca a condição dos estudos urbanos brasileiros sobre o crime está ligada à subnotificação e, sincronicamente, à falta de qualidade dos registros oficiais. Com relação à subnotificação de mortes violentas no âmbito da saúde, Minayo (1994) esclarece que as informações médicas recorrentemente classificam a causa dessas mortes como "outras violências" ou "lesões" (ignorando se foram acidentais ou intencionalmente infligidas), portanto uma parcela não desprezível das ocorrências, que poderia compor os indicadores de homicídios, não é nem mesmo notificada. Esse cenário também comporta a subnotificação na esfera da segurança pública, decorrente de cifras não contabilizadas de contravenções e transgressões previstas na legislação penal em vigor.

Não sem motivos, os sentimentos de insegurança e impunidade, associados ao descaso de atendimento nos postos policiais e a descrença dos cidadãos nas instituições promotoras de justiça, acentuam uma generalizada falta de confiança da população nas instituições encarregadas de aplicar lei e ordem, o que, por sua vez, estimula a não disposição das vítimas em reportar o crime de que tenha sido vítima. Entretanto, convém destacar, os homicídios dolosos são crimes que apresentam um número menor de subnotificações, dado a menor possibilidade de ocultação da materialidade do crime. Outrossim, o conhecimento da autoria é crucial para o processo de apuração da responsabilidade penal. Estudos sobre fluxo do sistema de justiça criminal, como os de Adorno (1994; 2002), Adorno e Pasinato (2010) e Misse (2010), demonstram que deficiências da investigação policial agravam a subnotificação de homicídios no Brasil, cuja proporção de esclarecimento varia entre $5 \%$ e $8 \%{ }^{4}$

Além disso, deve-se ressaltar a existência de mais um aspecto que, desde o último quartel do século passado, desafia os estudos urbanos sobre a criminalidade nesta sociedade: a emergência do crime organizado, especialmente em torno do tráfico de drogas, cujo impacto tem interferido na capacidade de o Estado deter o monopólio legítimo da coerção e exercer controle sobre a ordem pública. $A$ eclosão dessas organizações que funcionam, ora como poderes paralelos ao poder oficial ora mesclando-se às instituições oficiais de repressão aos crimes, tem promovido mudanças nos modelos e perfis do crime urbano, de acordo com diferenças regionais e singularidades sociais de cada estado brasileiro.

Em São Paulo, durante as décadas de 1980 e 1990, os homicídios e os crimes contra o patrimônio conheceram acentuado crescimento, especialmente nos bairros com elevada concentração de trabalhadores de baixa renda, precárias condições de infraestrutura urbana e de serviços públicos. Distintas situações com desfechos fatais, tais como mortes praticadas por justiceiros e grupos de extermínio, aquelas relacionadas a cobranças por dívidas de drogas ou decorrentes de disputas no domínio territorial do narcotráfico, caracterizavam, em grande medida, a dinâmica local da violência. Entretanto, à medida que o Primeiro Comando da Capital (PCC), nascido nos meados dos anos 1990, entrou na guerra do tráfico com o propósito de eliminar facções rivais e exercer monopólio local das atividades ilegais, esse cenário de insegurança sofreu nova inflexão, parecendo 
responder em parte pela queda dos homicídios que será verificada a partir dos anos 2000, conforme sustentarão alguns estudos (Feltran, 2011 e 2012). Mas, a pax monopolista do PCC ${ }^{5}$ foi capaz de efetivamente gerar efeitos locais, com impactos no estado de São Paulo como um todo, sobre a diminuição de homicídios?

Não obstante os profundos avanços alcançados pelos estudos urbanos, a diminuição da taxa paulista de homicídios dolosos, iniciada em 2001, ainda hoje não é inteiramente compreendida. Esse desconhecimento pode ser imputado à carência de informações, em parte pelo fato de se tratar de um fenômeno cuja quantificação, compreensão e explicação ainda depende do acúmulo de conhecimento no âmbito das ciências sociais.

Este artigo constitui um esforço no sentido de apresentar novos elementos e argumentos para 0 avanço desse debate.

\section{Primeiros estudos}

Os primeiros trabalhos quantitativos empíricos que buscaram avaliar correlações entre indicadores de urbanização e criminalidade em território paulista existem há mais de três décadas. Um deles foi elaborado por Pezzin e Macedo (1987), com dados de 1983, cujos resultados confirmam a existência de correlações positivas e significativas entre esses indicadores em relação aos crimes contra o patrimônio na Região Metropolitana de São Paulo (RMSP). É interessante observar que esse estudo não demonstrou correlação significativa relativamente aos crimes contra a pessoa. Conforme esses autores, no período focalizado, o pauperismo contribuía para a ocorrência de roubos e furtos, de modo que, quanto piores as condições sociais que caracterizavam a vida de grupos sociais determinados, maior o número de casos dessa espécie de crimes. Todavia, os homicídios não revelaram o mesmo comportamento, já que não pareceram significativamente afetados pela pobreza.

Os méritos dos primeiros estudos foram justamente: a) demonstrar as relações entre 0 desenvolvimento econômico-social e o movimento dos crimes; b) destacar a tendência de alguns delitos ocorrerem com maior frequência em lugares em que é maior a precariedade da infraestrutura urbana, caracterizada por pior oferta de postos de trabalho, de serviços de lazer e de cultura; e c) evidenciar a possível influência da crise econômica sobre as oportunidades de ingresso de novos integrantes em grupos delinquentes. Mas, convém lembrar, esses estudos foram produzidos em um período de transição política do regime autoritário para a democracia, no qual o argumento que estabelecia relações inexoráveis entre desigualdades sociais, capitalismo e violência tinha peso acadêmico. Em outras palavras, as violações de direitos e a evolução dos crimes e da violência compreendiam reações condicionadas por estruturas de exploração, dominação e exclusão inerentes ao Estado e ao sistema social, político e econômico vigentes à época. Relações causais entre baixa renda e crime eram convocadas para demonstrar a pertinência daquela hipótese teórica. As imagens de cidades cindidas entre um centro rico e "pacífico" e uma periferia pobre violenta pareciam expressar e materializar as lutas de classes (Zaluar, 1999). Portanto, uma sociedade pacificada, com crimes sob controle, somente seria alcançada com a abolição dessas 
lutas. Não demorou muito para que esses argumentos fossem submetidos à prova empírica (Zaluar, 2004).

Em meados dos anos 1980, a reflexão sobre o crime urbano estava apenas se iniciando. 0 gerenciamento estatal, antidemocrático e centralizado, promovido durante 0 regime militar (1964-1985), tornava quase impossível a obtenção de informações sobre a criminalidade violenta. A despeito, as estatísticas do Registro Civil, informadas pelos Cartórios de Registro Civil de Pessoas Naturais, constituíam-se como instrumento fundamental para o acompanhamento dos óbitos de natureza violenta da população brasileira, ${ }^{6} \mathrm{e}$ assim é até hoje (Gráfico 1).

Os dados do Registro Civil comprovam o aumento da violência no País. No período de 1974 a 2016, as estatísticas denotam a abrangência nacional da elevação do número de ocorrências, com oscilações, a forte tendência de seu crescimento e a maior gravidade desse avanço nos grandes centros urbanos, o que acabou por consolidar os óbitos por agressão como um problema de saúde pública. Nota-se em São Paulo a gravidade desse avanço, com grande peso nas taxas nacionais (Gráfico 2).

Aproximadamente um quarto de todos os óbitos de natureza violenta ocorridos no Brasil aconteceu no estado de São Paulo. Entre 1974 e 1990, a taxa de mortalidade por violência cresceu aproximadamente $30 \%$, passando de $44,4 \%$ por 100 mil habitantes para $57,6 \%$, o que correspondia a cerca de 38 mil mortos a mais, se compararmos o primeiro e o último ano do período. Nos últimos anos da década de 1990, a RMSP, em geral, e a cidade de São Paulo, em particular, figuram como os lugares mais violentos do País e alguns dos centros urbanos mais violentos do mundo, com taxas sempre superiores a 80 mortos por grupo de 100 mil habitantes.

Gráfico 1 - Evolução dos óbitos de natureza violenta, no Brasil, estado de São Paulo, região metropolitana e município de São Paulo, para o período 1974-2016

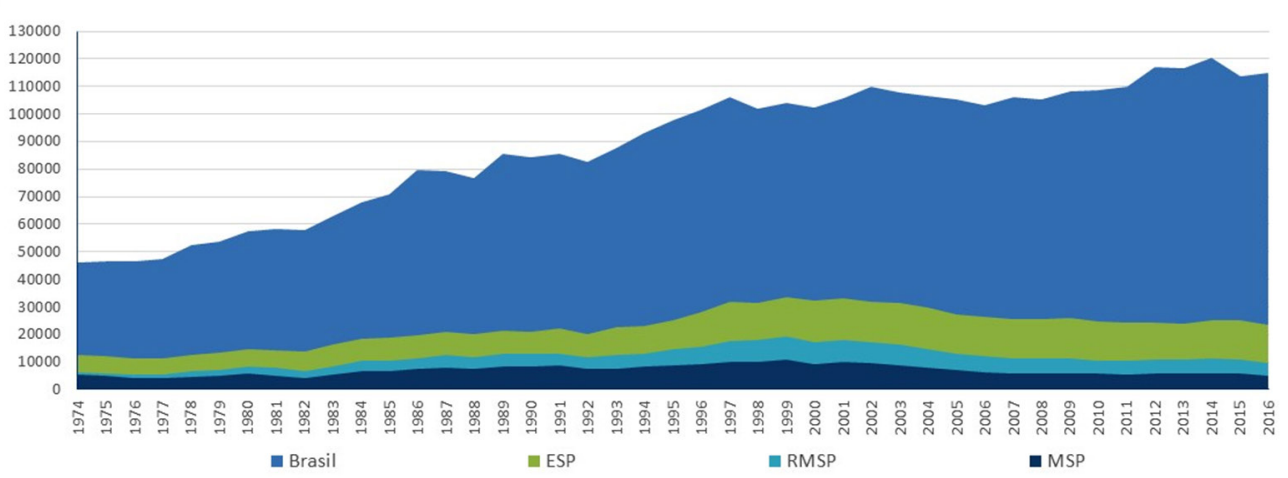

Fonte: IBGE - Estatísticas do Registro Civil. 
Gráfico 2 - Evolução das taxas de óbitos de natureza violenta por 100 mil habitantes, no Brasil, estado de São Paulo,

região metropolitana e município de São Paulo, para o período 1974-2016

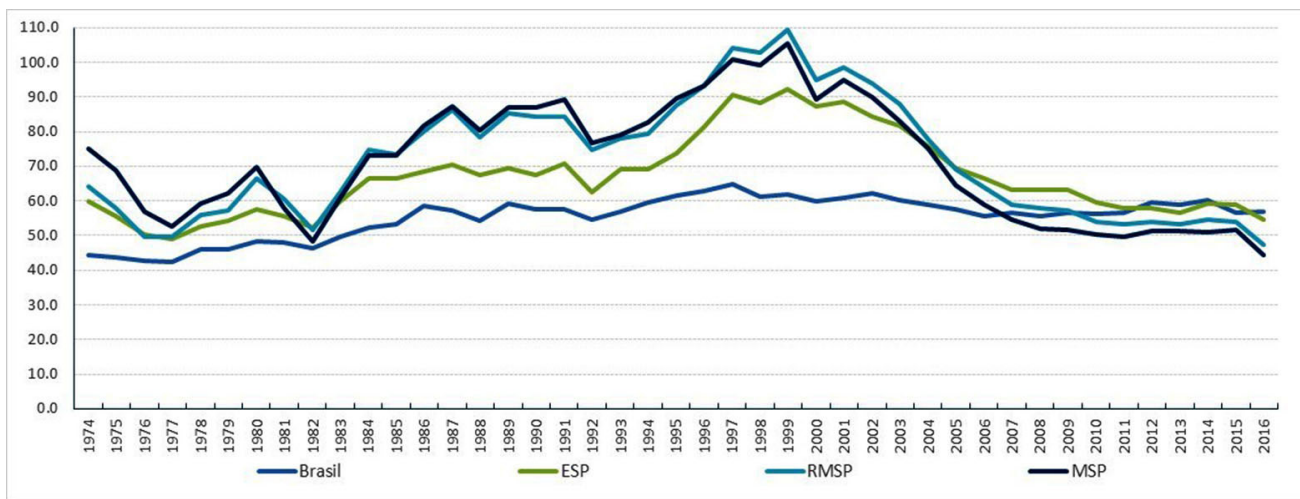

Fonte: IBGE - Estatísticas do Registro Civil; Projeção da População do Brasil para o Período 1980-2016. ${ }^{7}$

Essa condição pode ser mais bem observada, tendo em vista a atípica situação paulista com relação aos dados criminais. Em Mello Jorge (1981), é possível encontrar informações que remontam à década de 1960. Segundo a autora, levando em conta todos os homicídios ocorridos na capital paulista, os aumentos verificados de 1960 para 1965 e de 1965 para 1970 foram, respectivamente, de 69,3\% e de $82,9 \%$. Entre 1970 e 1975, o avanço foi de $19,3 \%$, redundando em uma taxa final de $59,2 \%$ por 100 mil habitantes.

De fato, apesar de todas as inconsistências e ambiguidades que podem ser atribuídas aos números oficiais, é possível afirmar que São Paulo conta com uma substancial série histórica de dados em escala urbana. Isso porque, além dos dados do Registro Civil, desde meados da década de 1970, os paulistas também dispõem de informações policiais que permitem mensurar e acompanhar a evolução dos homicídios em sua maior região metropolitana (Gráfico 3) - informações geradas pelo Departamento Estadual de Ordem Política e Social (Deops) ${ }^{8}$ e, depois, pelo Departamento de Planejamento e Controle da Polícia Civil (Deplan) ${ }^{9}$ e pelo Departamento de Homicídios e de Proteção à Pessoa (DHPP). ${ }^{10}$

Ao analisar a evolução dos homicídios, verifica-se que os números obtidos das fontes policiais são sempre menores, comparativamente aos fornecidos pelas fontes sanitárias. Até 1990, em toda a Região Metropolitana, incluindo a capital, foram registradas, segundo os agentes de saúde, 48.861 mortes por homicídios e, segundo os agentes segurança, 38.016 homicídios dolosos. Estendendo esse cálculo para o período 1981-2016, temos, em média, uma diferença anual de aproximadamente 460 homicídios a mais. Entretanto, cabe salientar que ambas as fontes apresentam o mesmo movimento, ou seja, apontam para aumento 
Gráfico 3 - Evolução do número de homicídios registados pela polícia civil e pelo registro civil/atestado de óbito, no município e região metropolitana de São Paulo*, para o período 1981-2016

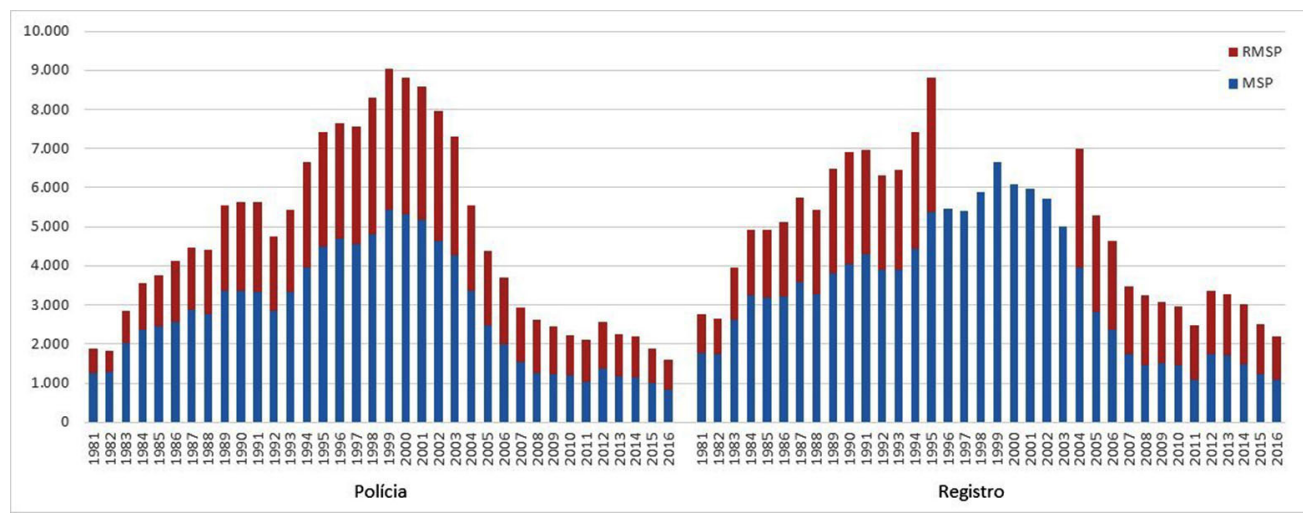

Fonte: Caldeira (2000); Polícia Civil (homicídio doloso, 1981-1995); Registro Civil (homicídio 1981-1995; ${ }^{11}$ Secretaria de Segurança Pública - SSP-SP - RES SSP 160/01 (homicídio doloso, 1996-2016); Fundação Sistema Estadual de Análise de Dados - Seade - Anuário Estatístico do Estado de São Paulo (mortes por agressão, 1996-2003); ${ }^{12}{ }^{13} 14$ Movimento do Registro Civil (mortes por agressão, 2004-2016)..$^{15}$

* Exceto MSP.

Gráfico 4 - Evolução das taxas de homicídios registados pela polícia civil e pelo registro civil/atestado de óbito, por 100 mil habitantes, no município e Região Metropolitana de São Paulo*, para o período 1981-2016

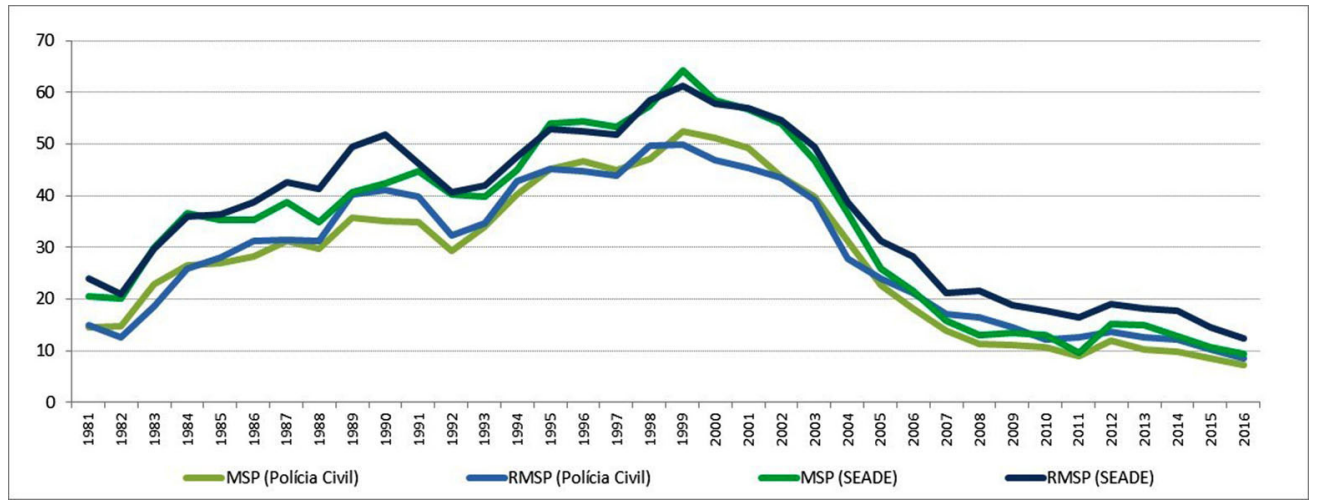

Fonte: Caldeira, 2000; Polícia Civil (homicídio doloso, 1981-1995); Registro Civil (homicídio 1981-1995); ${ }^{16}$ Secretaria de Segurança Pública - SSP-SP - RES SSP 160/01 (homicídio doloso, 1996-2016); Fundação Sistema Estadual de Análise de Dados - Seade - Anuário Estatístico do Estado de São Paulo (mortes por agressão, 1996-2003); ${ }^{17} 1819$ Movimento do Registro Civil (mortes por agressão, 2004-2016); ${ }^{20}$ IBGE - Projeção da População do Brasil para o Período (1980-2016). ${ }^{21}$

* Exceto MSP. 
(intermitente) até 1999 e decréscimo (contínuo) nas duas décadas subsequentes. Embora os dados para o ano de 2012 sejam exceção, nos demais, as curvas indicativas da evolução das taxas de homicídios revelam idêntica tendência (Gráfico 4).

Em outras palavras, o fato de as tendências serem as mesmas atesta que tanto os dados policiais como os dados da saúde captam com semelhante rigor a evolução geral da mortalidade por atos violentos na cidade e na RMSP. ${ }^{22}$

\section{Das grandes tendências às análises intraurbanas}

Nos anos 1990, em São Paulo, a produção de novos dados possibilitou novas reflexões e tematizações. No ano de 1995 são promulgadas a lei n. 9.155 e a resolução SSP n.161, que dispunham sobre a obrigatoriedade da publicação dos dados da Secretaria de Segurança do Estado por meio do Diário Oficial. Os números divulgados relativamente a domínios geográficos menores (MSP, RMSP e interior) demonstravam que os homicídios estavam claramente distribuídos de forma heterogênea, tal qual as tendências de suas taxas. Ao comparar o interior paulista com a RMSP, por exemplo, observaram-se variações menos acentuadas, assim como a inexistência de paralelismo entre curvas (Gráfico 5).

No fim da década, as inovações tecnológicas possibilitaram examinar as tendências das taxas de homicídios em maior detalhe, permitindo, em contrapartida, rever assertivas anteriores e conferir maior precisão às análises. Entre as inovações que mudaram a produção de dados criminais, em escala e detalhe, três merecem destaque.

Gráfico 5 - Evolução das taxas de homicídios e homicídios dolosos, por 100 mil habitantes, no estado de São Paulo, região metropolitana, Interior e Município de São Paulo*, para o período 1996-2016

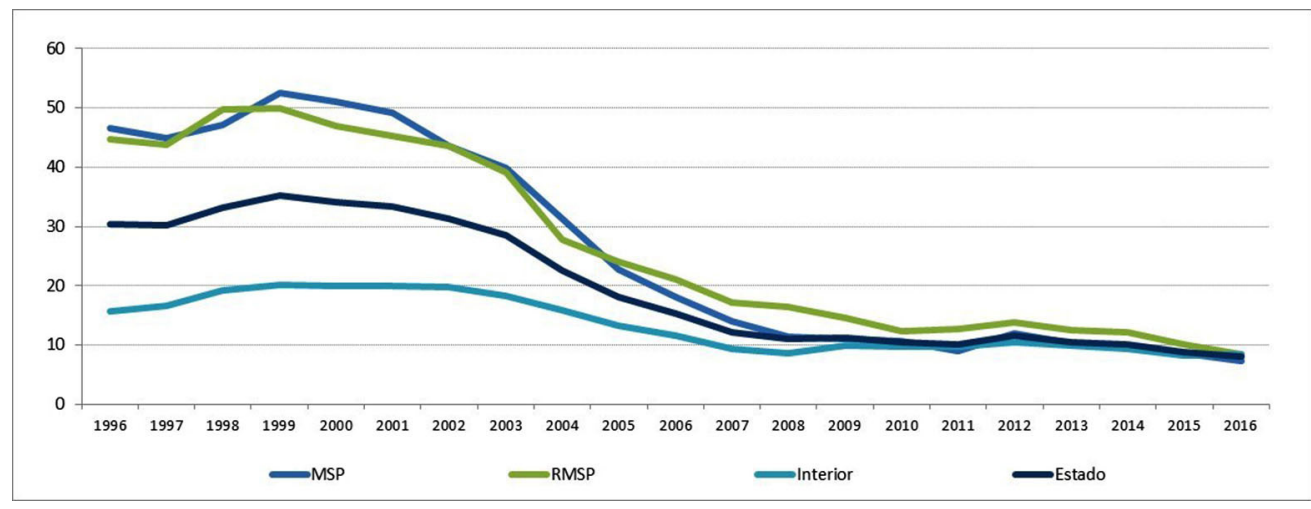

Fonte: SSP-SP - RES SSP 160/01 (homicídios dolosos); Fundação Sistema Estadual de Análise de Dados - Seade (população residente).

* Exceto MSP. 
Primeiramente, a implementação, em 1999, do Infocrim (Sistema de Informações Criminais), um banco de dados informatizado que interligou as redes dos distritos e companhias policiais e que ofereceu dados como local, data, horário e natureza das ocorrências, locadas em um mapa digital. Em segundo lugar, em 2000, ocorreu a alteração e a compatibilização dos limites territoriais das áreas de atuação das polícias civil e militar no município de São Paulo, determinando nominalmente os logradouros que compunham o perímetro de cada distrito policial da capital (Resolução SSP n. 245). Finalmente, em 2001, a criação do Sistema Estadual de Coleta de Estatísticas Criminais especificou as estatísticas de ocorrências criminais registradas e uniformizou o fluxo de dados coletados (Resolução SSP n. 160).

Por si só, essas mudanças poderiam ser um marco para os estudos sobre os crimes registrados em territórios paulistas, diferenciando-os dos resultados alcançados em investigações anteriores. Entretanto, mais um fato veio agregar-se a esse cenário de mudanças institucionais. Em 1999, a taxa de homicídios, no município de São Paulo, alcançava o maior valor já registrado com mais de 50 mortos por grupos de 100 mil habitantes, segundo a polícia civil, e aproximadamente 65 por 100 mil, segundo os dados da saúde - resultados análogos apenas à estimativa do já citado estudo de Mello Jorge (1981) em 1975.

Em 2000, as taxas de homicídios foram menores que as de 1999, interrompendo a elevação dos dois anos anteriores. Até esse momento, não havia nenhuma novidade, porque, a despeito da tendência de crescimento, observavam-se quedas nas taxas de um ano para outro nas décadas de 1980 e 1990 (Gráfico 4).
Outrossim, o mesmo ocorre em 2001 e 2002, quando se começa a considerar que a redução poderia não ser uma condição temporária e sim uma nova tendência que se manteria. Essa avaliação surpreendeu a todos, à época, e a perplexidade aumentou à medida que a tendência contínua e acelerada de queda nas taxas de homicídios (Gráficos 4 e 5) se confirmava.

0 município de São Paulo, que em 1999 ocupava a segunda posição entre as capitais brasileiras mais violentas, desde 2015 ocupa o último lugar com a taxa mais baixa do país (FBSP 2016; 2017; 2018). Não demorou muito para o surgimento de várias explicações para essa queda. É interessante notar, entre as primeiras teses explicativas para essa tendência, a hipótese segundo a qual estaria havendo um deslocamento dos polos dinâmicos da violência das grandes cidades para cidades menores não era corroborada pelos dados, uma vez que essa mesma tendência de redução das taxas metropolitanas não estava sendo observada no interior do Estado (Waiselfisz, 2007).

Os fundamentos dessa tese não devem ser desprezados. Essa proposição baseou-se na avalição do conjunto de dados criminais que, agora acessíveis, permitia analisar com maior rigor o MSP e os municípios da RMSP e do interior do estado separadamente (Gráfico 5). Sob essa perspectiva, não é estranho que os argumentos mobilizados para sustentar aquela hipótese fossem buscados nas chamadas "teorias da modernização", ${ }^{23}$ que se fundam em uma concepção linear do desenvolvimento econômico-social, resultante da intersecção entre industrialização, urbanização e comportamento coletivo. Por certo, a comprovação daquela hipótese, sustentada nas teorias da modernização, reclamava 
demonstração empírica, pois, mesmo quando eram encontradas relações entre proxies de vida urbana e criminalidade, as explicações ensejavam argumentos mais sofisticados e interpretação teoricamente mais complexa.

No que diz respeito aos homicídios, por exemplo, é forçoso reconhecer relações condicionadas por fatores que atuam em distintos níveis - macro/global e micro/local. Inicialmente cabe compreender que esses níveis se entrecruzam e que ambos são basilares para o entendimento amplo da realidade criminal. Não obstante, ambos os níveis revelam dois lados da mesma moeda. Sob a perspectiva macro/ global (mundial, nacional, regional, metropolitana), o foco incide na identificação de determinadas regularidades em grandes escalas territoriais. Do ponto de vista micro/local (intraurbano), o foco se desloca para a compreensão das diacronias de uma dada localidade ou região. Assim, diante desses ângulos de observação, o ideal seria que se levasse em conta a estreita articulação entre dimensão macro com aquilo que são as especificidades de cada território. Porém, muitas vezes isso não acontece. Com maior frequência, os padrões de criminalidade são examinados segundo áreas extensas, omitindo-se as influências procedentes de seu mosaico de características demográficas, sociais, econômicas, etc. Por certo, não se trata de uma preferência analítica ou de um habitus dos analistas, porém resulta, em grande medida, da falta de dados pontuais ou associados a pequenas unidades de área, adequados para os estudos científicos.

Entre os dados micro/local de abrangência nacional merecem destaque os produzidos pelo Instituto Brasileiro de Geografia e Estatística (IBGE), sobretudo os oriundos dos censos.
Como se sabe, o IBGE realiza, a cada 10 anos, o censo demográfico, e é, nessas ocasiões, que sua base de setores é atualizada. Setor censitário é uma unidade estabelecida para a coleta de dados em função do perímetro urbano, abrangendo, em áreas urbanas, cerca de 250 a 350 domicílios. Essa unidade territorial, a menor na qual informações populacionais são coletadas sistematicamente e se encontram disponíveis, revela-se mais adequada para análises intraurbanas (Alves, 2006; Nery, 2006) assim como dos padrões e variabilidade espaço-temporais dos homicídios dolosos (Nery et al., 2012, 2016).

Voltando à situação paulista, os dados das Prefeituras, da Companhia do Metropolitano de São Paulo (Metrô/SP), da Empresa Paulista de Planejamento Metropolitano (Emplasa) e da Fundação Seade não podem ser ignorados, pois contribuem para o refinamento das análises. Provenientes dessas instituições, os registros de mortalidade e morbidade, as características das viagens diárias da população, as áreas de risco (geológico), de expansão urbana e de proteção aos mananciais são algumas das informações essenciais para os estudos urbanos atuais.

Enfim, devemos relembrar que, desde de 1999, com o Infocrim e depois também com o Copom on-line, ${ }^{24}$ a Secretaria de Segurança de São Paulo produz dados pontuais geocodificados de crimes, permitindo sua visualização e análise. Hoje todos os municípios do estado contam com esses dados, no entanto no primeiro ano eles foram gerados apenas para a capital (Figura 1).

Importante ressaltar, somente no desenlace do século XX, a localização no mapa com alfinetes foi substituída pela geocodificação. 
Figura 1 - Densidade de homicídios dolosos, ${ }^{25}$ no município de São Paulo, em 1999

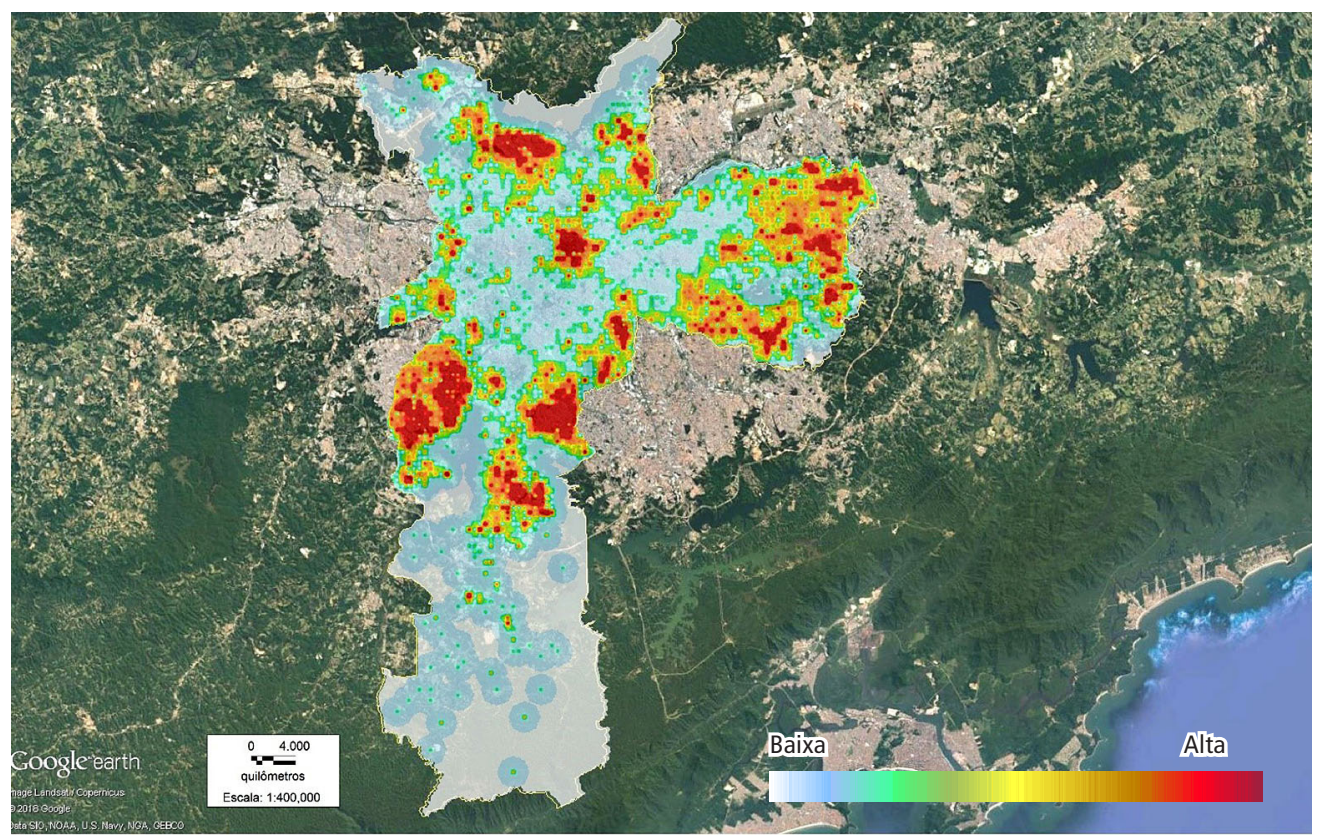

Fonte: Infocrim/SSP-SP. Elaborado pelos autores.

Assim que isso aconteceu, saltava aos olhos a concentração de homicídios em alguns pontos específicos da cidade. Ao analisar as superfícies interpoladas, as altas densidades destacavam-se, no município de São Paulo, nos distritos censitários de Brasilândia e Cachoeirinha, na zona Norte; Sé, República e Brás, na região Central; Jaguaré e Vila Leopoldina, na zona Oeste; Jardim Helena, Itaim Paulista, Vila Curuçá, Lajeado, Itaquera, José Bonifácio, Guaianazes, Sapopemba, São Rafael e São Mateus, na zona Leste; Capão Redondo, Campo Limpo, Jar$\operatorname{dim}$ São Luís, Jardim Ângela, Jabaquara, Cidade Ademar, Cidade Dutra e Grajaú, na zona Sul. ${ }^{26}$
De modo geral, a primeira avaliação não causou surpresa, dado que, no senso comum, estava arraigado o medo difuso quanto à periculosidade de bairros, principalmente de favelas, nos referidos distritos (Caldeira, 2000). A "região" 27 do Jardim Ângela, por exemplo, já em 1996 era apontada pela Organização das Nações Unidas (ONU) como a mais violenta do mundo. Entretanto, essa avaliação estava distante de atingir toda a verdade, porque também se podia constatar que as maiores concentrações de assassinatos ocorriam em localidades distintas daquelas antes tidas como violentas, ${ }^{28}$ como o centro da capital onde eram observadas 
altas intensidades, similares às dos bairros mais violentos do perímetro paulistano. Esse fato vem em socorro à sustentação de uma hipótese distinta da anterior e que se nos afigura essencial para os estudos urbanos do século XXI: São Paulo pode ser classificada como uma cidade violenta; entretanto, o mais correto é vê-la como uma cidade que congrega lugares muito violentos e diversamente pacíficos - não de forma dicotômica e simplificadora e certamente não em um modelo centro-periferia.

\section{Possível elenco de causas sociais e grandes marcos históricos}

Se os novos dados trazidos às análises corroboravam a célere queda dos homicídios dolosos na capital paulista (Gráficos 2 a 5), não apontavam suas causas. Efetivamente, a explicação da variabilidade espacial dos homicídios não encontrava respaldo nos argumentos mais mobilizados à época. Analisadas de forma estanque, possíveis causas associadas às "políticas de segurança pública", às "medidas e intervenções municipais", às "ações de organizações criminosas" ou às "mudanças demográficas" 29 não esclareciam porque, em certas partes do território urbano, as taxas eram altas, enquanto, em outras, baixas; ou, ainda, porque a redução das taxas era maior e mais rápida em dadas localidades, ao passo que menor e mais branda em outras. Tais constatações suscitavam novas questões e colocavam em descrédito modelos preestabelecidos para explicar as relações entre a vida e a organização nas cidades e os padrões de crime urbano.
De tudo o quanto se disse neste artigo, o que foi possível aprender? Em linhas gerais, fundamentalmente três pontos inter-relacionados. Primeiramente, as mensurações de homicídios agregadas em grandes áreas (como regiões e cidades metropolitanas) permitem somente avaliar tendências gerais e apresentar considerações, por certo importantes, todavia genéricas. 0 segundo ponto, a causalidade entre essas mensurações e aquelas que pretendem explicá-las deve ser tomada como um princípio capaz de esclarecer nexos causais. 0 terceiro ponto é a impossibilidade de atribuir a uma única causa as alterações nas taxas de homicídios.

Tendo isso em mente, o que vimos descobrindo a respeito das tendências gerais dos homicídios em São Paulo leva a afirmar que os volumes populacionais (densidade demográfica e crescimento populacional), a infraestrutura urbana (acesso a equipamentos públicos de educação, saúde, lazer e segurança), a condição de moradia (áreas de exclusão social) e as características acerca de gênero, idade e raça/ cor são elementos indispensáveis dos modelos explicativos do movimento dos homicídios (Cardia e Schiffer, 2000; Adorno, 2002; Peres et al., 2011). Esse conjunto de fatores se mostra importante tanto por conter potenciais causas explicativas do crescimento ou da retração das mortes violentas, como por permitir melhor entender a distribuição espaço-temporal dessas mortes no território urbano.

Não obstante, a referida importância deve ser ponderada, e os três trabalhos supracitados permitem, quando menos, destacar dois ilustrativos exemplos dessa ponderação: os "bairros dormitórios", cuja população é obrigada a deslocar-se por longas distâncias para se 
dirigir ao trabalho, comumente caracterizados pela carência de serviços públicos e pelo alto congestionamento habitacional, apresentam maior predisposição para desfechos fatais em conflitos sociais, interpessoais e intersubjetivos. Esses bairros foram formados em diferentes períodos e passam por diferentes processos de urbanização, os quais dependem de contextos temporais e das características que definem as espacialidades locais - isto é, os modos como os espaços e territórios são ocupados tanto para fins de moradia como para fins de comércio, demais atividades econômicas e prestação de serviços públicos. Logo, esses bairros são diversos e exibem diferentes estratos de risco para mortalidade violenta. ${ }^{30}$

Outro exemplo pode ser encontrado através da avaliação da tendência das taxas de homicídios para o grupo considerado de maior risco, isto é, homens, jovens, negros. Sob essa perspectiva, era de se esperar que, para esse grupo, as taxas revelassem um comportamento mais resiliente; contudo, a queda de homicídios no município de São Paulo teve início antes, em 1999, para a população de raça/cor negra, enquanto, para a população de raça/cor branca, a queda teve início apenas em 2001, ano que também marca o início da tendência global de redução dos homicídios na cidade ${ }^{31}$ (Figura 2).

Evidencia-se, então, a necessidade de analisar o comportamento dos homicídios em função da heterogeneidade espacial paulistana e de um período de tempo relativamente longo. Adicionalmente, Nery et al. (2014) identificam a complexidade da variabilidade dos homicídios dolosos. Segundo esse estudo, essa variabilidade não está sempre ou necessariamente relacionada com melhorias econômicas e de infraestrutura, tampouco com o perfil demográfico-social, entre outros. É possível que, em algumas localidades, a melhora no acesso a direitos econômicos e sociais, por exemplo, coexista com a manutenção ou até mesmo com o avanço dos homicídios.

Sob uma perspectiva longitudinal, esse artigo sustentou a existência de três marcos temporais na evolução dos homicídios na cidade de São Paulo. 0 primeiro em 1975, quando a taxa de homicídios se aproximou de 60 por 100 mil habitantes; o segundo, em 1999-2000, um momento de inflexão e mudança de tendência dessas taxas; o terceiro em 2001, a ocasião em que se verifica o começo da tendência global de redução dos homicídios. 0 ano de 2005 pode ser considerado o quarto marco. Isso porque, anteriormente, a melhor maneira de explicar a variabilidade das taxas de homicídio era, sem dúvida, empregando-se as taxas do ano anterior (Nery, 2016); depois, além desse pressuposto ter perdido sua força analítica e explicativa, surge um novo fator a ser seriamente considerado: a influência da facção criminosa denominada Primeiro Comando da Capital (PCC) sobre as taxas de mortes violentas torna-se difícil de ser contestada ou ignorada.

Cabe assinalar que todos esses eventos estão interligados. Os atentados do PCC, iniciados em maio de 2006, parecem indicar 0 desfecho do conflito entre facções criminosas e do ciclo de vinganças que marcava o cotidiano da capital paulista há cerca de três décadas, a ponto de alterar a dinâmica espaço-temporal dos homicídios. A propósito, o exame de estudos que tratam da contribuição da hegemonia (PCC) para a redução das taxas de homicídios permite, grosso modo, subsidiar essa hipótese (Biderman et al., 2014; Dias, 2013; Manso e Dias, 2018; Feltran, 2011 e 2018). Esses 
Figura 2 - Densidade de homicídios dolosos, ${ }^{32}$ no município de São Paulo, no período 2000-2005

2000

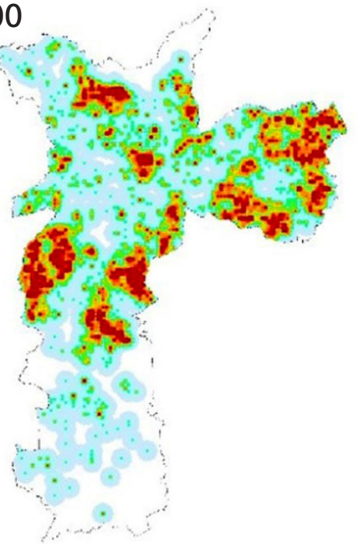

2003

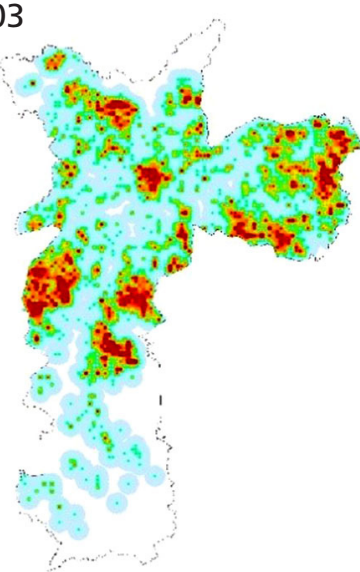

2001

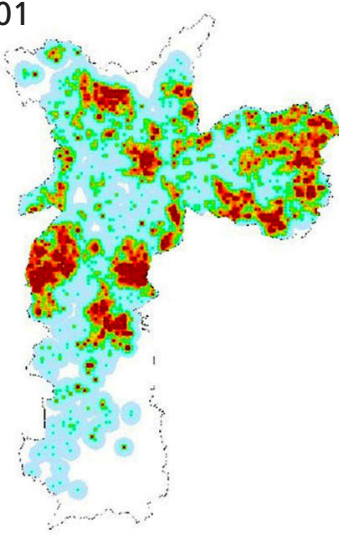

2004

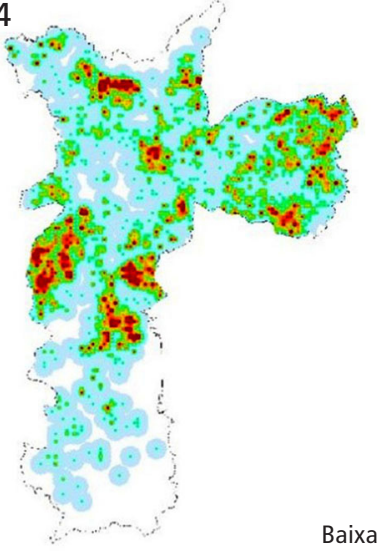

2002

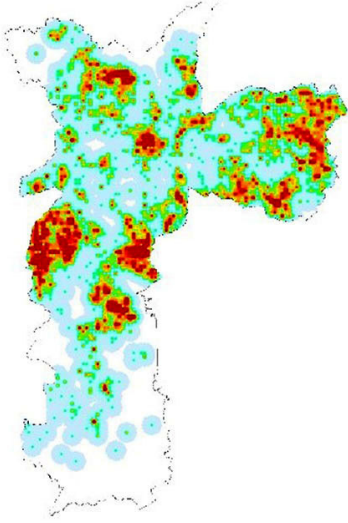

2005

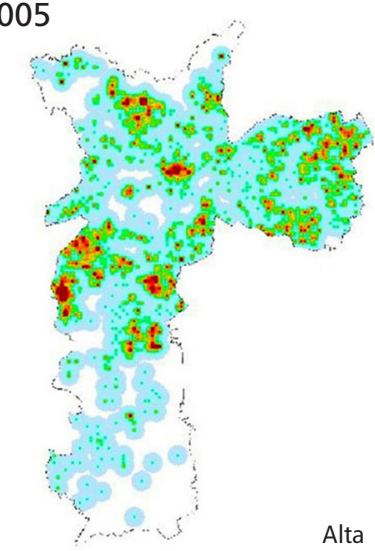

Fonte: Infocrim/SSP-SP. Elaborado pelos autores.

estudos apontam para a hegemonia alcançada pelo PCC na gestão dos conflitos diversos da vida cotidiana nos bairros nos quais tem destacada presença, segundo rígida regulação das condutas públicas e privadas, que dispensa punições às transgressões.

Neste ensaio, não se pretendeu avançar nesta direção, a de explicar o peso dessa organização criminal na redução das taxas de homicídio. De todo modo, convém colocar em destaque o momento a partir do qual essa influência deve ser observada com maior cuidado nos estudos que abordam as relações entre crime urbano e desenvolvimento das cidades. Aliás, essa advertência já tinha sido apontada em outro de nossos estudos (Adorno, Dias e Nery, 2016). Nesse estudo, sugerimos que 0 poder de regulação sobre as mortes é exercido 
e tem efeitos distintos, conforme as características dos bairros de São Paulo.

Por fim, o ano de 2006 e o período 2012-2013 devem ser levados em conta pelo agravamento de uma situação que historicamente afeta a população paulista. Após os atentados de 2006 e, sobretudo, depois do amplo conflito estabelecido entre a Polícia Militar (PM) e os criminosos ligados ao PCC, em 2012, as mortes em confronto com a PM, já elevadas, aumentaram significativamente. 0 número de pessoas mortas em confronto com a PM na capital aumentou $100 \%$, entre 2005 e 2006, e 40,4\%, entre 2011 e 2012, passando de 132 para 264 e de 230 para 323 ocorrências, respectivamente.
Em decorrência, dois acontecimentos se sucederam. Primeiro, o número de homicídios dolosos cresceu de forma expressiva na cidade de São Paulo; os assassinatos apresentaram um aumento de $34,2 \%$, passando de 1.019 assassinatos, em 2011, para 1.368, em 2012 (Gráfico 3), interrompendo a tendência de queda nas taxas de homicídios (Gráficos 4 e 5). Segundo, após uma pronunciada queda, em 2013, as mortes em confronto com a PM voltaram a crescer rapidamente e, em 2016, foram responsáveis por aproximadamente um terço de todas as mortes violentas cometidas por terceiros na cidade de São Paulo (Gráfico 6).

Sem dúvida, desde há muito tempo, as políticas de segurança concentradas em torno

Gráfico 6 - Percentual de pessoas mortas em confronto com as polícias com relação ao total de mortos por terceiros, ${ }^{33}$ no estado de São Paulo, região metropolitana, interior e município de São Paulo*, para o período 1996-2016

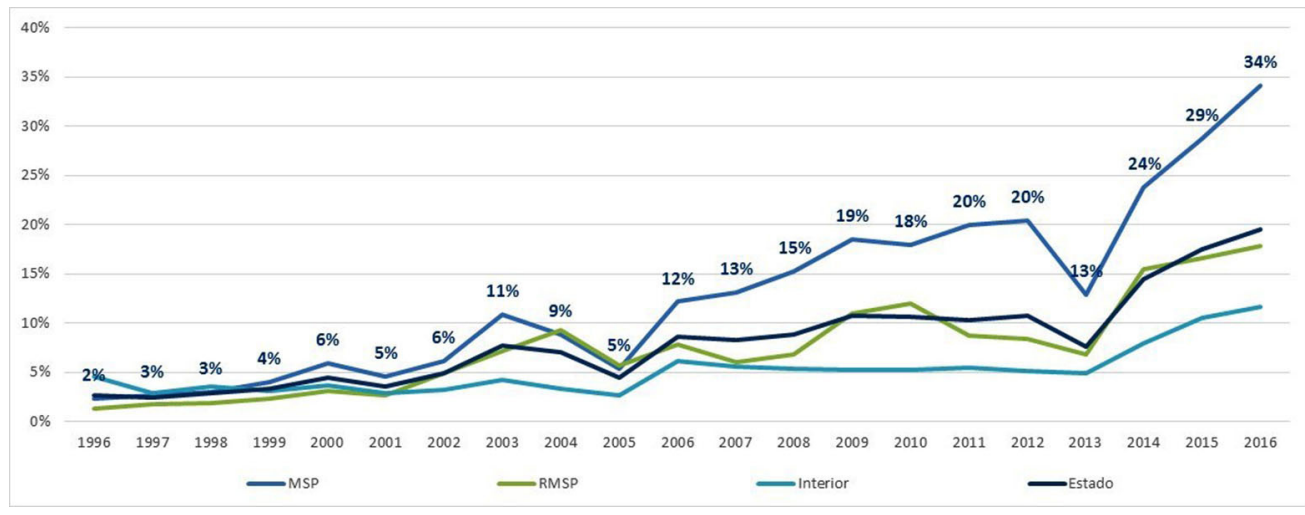

Fonte: SSP-SP - RES SSP 160/01.

* Exceto MSP. 
da repressão aos crimes se tornaram um artifício de diferentes governos, a ser acessado em períodos de crise. Não por acaso, os estudos urbanos sobre essas políticas revelam a fragilidade do equilíbrio entre segurança, violência e eficácia da ação policial (Porto, 2001). Entre esses estudos, aqueles que se dedicam à análise dessas modalidades de ação institucional demonstram a violência policial associada às execuções sumárias e às mortes decorrentes de confrontos entre o PCC e as forças de segurança do estado (Feltran, 2012). No mesmo sentido, demonstram essa modalidade de violência institucional influenciando os coeficientes de mortalidade por homicídio, favorecendo ainda mais violência (Peres et al., 2008), e estimulando a sensação de insegurança da população, como veremos por fim.

\section{Trajetórias futuras}

Acesso a dados qualificados e sistematizados, análises macro/micro, entendimento da multicausalidade, identificação de espaços intraurbanos, caracterização de variabilidade e padrões espaço-temporais, influência do crime organizado e das políticas públicas de segurança compõem um cenário que não pode ser ignorado pelos estudos urbanos de vários campos científicos, sobretudo os campos dedicados às pesquisas do crime em grandes cidades. Nesse cenário, as dificuldades são grandes, mas as perspectivas para o futuro não são menores.

Tal constatação, ao mesmo tempo que destaca a necessidade de um número significativo de estudos urbanos, nas mais diversas áreas, reconhece que hoje existem novos pontos de partida capazes de romper os dualismos que, por muitos anos, consagraram os nexos conceituais de vários desses estudos. Sobre esse ponto, este artigo se encerra com a descrição de dois dos resultados mais recentes alcançados com a pesquisa Building Democracy Daily: Human Rights, Violence and Institutional Trust, desenvolvido pelo Núcleo de Estudos da Violência (NEV) da Universidade de São Paulo (Cepid-Fapesp). ${ }^{34}$

Esse projeto institucional foi construído a partir de resultados de projetos de investigação realizados pelo NEV-USP ao longo de seus trinta anos de existência, indicativos de acentuadas desconfianças dos cidadãos, procedentes dos mais distintos estratos socioeconômicos, em relação à aplicação universal das leis, ao desempenho dos agentes públicos e ao papel das instituições encarregadas de promover justiça. Ele tem como objetivo explorar questões relacionadas a confiança e legitimidade de instituições-chave para a democracia. A pesquisa, que se vale principalmente de dados de surveys transversais e longitudinais, está organizada em três dimensões: a) perspectiva dos adolescentes: explora o processo de socialização legal desde a primeira adolescência, acompanhando o desenvolvimento das relações de jovens com as autoridades e definição de regras em casa, na escola e no contato com policiais; b) perspectivas dos cidadãos: explora as relações entre o público e as autoridades, investigando quais são os condicionantes da legitimidade das leis, da justiça e da polícia, além de considerar como essas relações podem ser afetadas por variáveis socioespaciais e experiências de medo e vitimização; c) perspectiva dos detentores do poder: como servidores públicos, como policiais 
e juízes, entendem sua própria legitimidade e percebem o seu exercício de autoridade.

Para lidar com os desafios impostos pela heterogeneidade urbana e com o objetivo de fundamentar a amostra da pesquisa com os residentes do município de São Paulo, o NEV desenvolveu uma metodologia denominada "áreas-chave" (Nery et al., 2015). Para construir tal metodologia, foi preciso selecionar as variáveis de interesse e compatibilizar as informações em termos espaciais e temporais. Os dados secundários, oriundos de agências e instituições públicas (IBGE, Metrô/SP, Emplasa, Seade, etc.) indicam aspectos considerados relevantes para a compreensão das desigualdades socioespaciais paulistanas: características ambientais, domiciliares, demográficas, criminais, socioeconômicas e de mobilidade. Tendo em vista que as informações produzidas por essas instituições têm como referência diferentes unidades territoriais e levando-se em consideração a perspectiva intraurbana, adotou-se 0 setor censitário do Censo Demográfico de 2010 como a unidade territorial base (quando foram contabilizados quase 19 mil setores censitários), para os quais foram atribuídos os dados das características selecionadas.

0 resultado foi a estratificação do território municipal em diferentes padrões urbanos e demográficos (grupos de setores censitários, excludentes entre si e internamente homogêneos) e a subsequente delimitação de subáreas, o que assegurou a representatividade amostral relativa à heterogeneidade e à hierarquização espaciais que caracterizam a metrópole paulistana. ${ }^{35}$ Grosso modo, foram encontradas oito urbes distintas na cidade de São Paulo (Figura 3).

Concomitantemente, a pesquisa também constatou os efeitos do contexto político, social e histórico sobre as mensurações do crime (as informações geradas pelos agentes de segurança, assim como os dados primários obtidos, por exemplo, em pesquisas de opinião). Acontece, pois, que, dentro desse contexto, o medo tem apresentado os resultados mais promissores; em síntese, existe uma relação entre medo e as estatísticas criminais - mesmo em um contexto de queda dos homicídios (Gráficos 2 a 5).

Esse método de estratificação do território está possibilitando abordagem mais refinada do impacto da heterogeneidade econômico-social e institucional sobre a credibilidade conferida aos agentes encarregados de aplicar as leis e instituições que regulam, por exemplo, o controle legal da ordem pública em uma metrópole como São Paulo. Por exemplo, uma das questões mais sensíveis para avaliar a credibilidade e legitimidade de instituições nesse campo da intervenção governamental é o medo da polícia.

Conforme Adorno e Pasinato (2010), ao menos em São Paulo, são acentuadas as imagens ambíguas da polícia entre os cidadãos. Por um lado, para muitos moradores, sobretudo em bairros com precária infraestrutura urbana e de instituições de promoção social, a polícia é vista como capaz de exercer tarefas que não são de sua competência (como prestar assistência em casos de parto); por outro, a polícia aparece associada ao crime e à violência desmedida. Não sem motivos, equiparam-se o medo da polícia com o medo do traficante. Essa questão, dada as relevâncias para o êxito de políticas públicas de segurança, tem sido objeto de atenção especial, ensejando análises detalhadas, presentemente em curso.

De acordo com a literatura especializada, obedecer à polícia é um dos requisitos do 
Figura 3 - Padrões urbanos, ${ }^{36}$ no município de São Paulo, em 2010

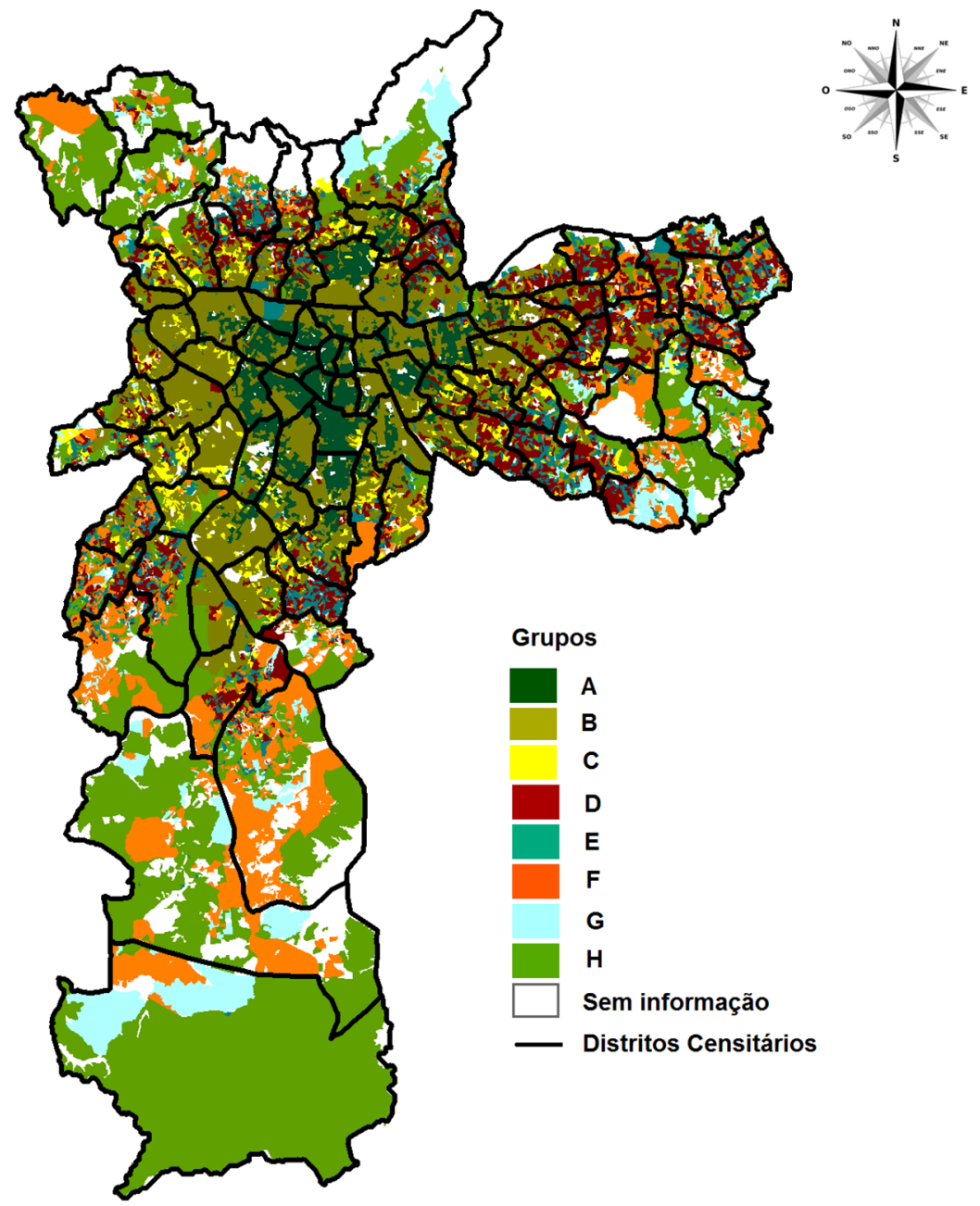

Fonte: Núcleo de Estudos da Violência (Nery et al., 2015).

Estado democrático de direito e da proteção à segurança para maior número de cidadãos. 0 problema é saber em que repousa essa obediência. Ela pode resultar do reconhecimento da autoridade policial e de seu direito a emitir comandos - em consonância com sua função de servir e proteger os cidadãos. Nessas circunstâncias, a obediência resulta de motivos de ordem racional através dos quais os cidadãos são levados a crer que obedecer é uma virtude. Nesse caso, prevalecem argumentos segundo os quais compartilhar valores que beneficiam maior número - como assegurar segurança pública - deve prevalecer sobre 
quaisquer interesses individuais. No entanto, pode ocorrer o contrário. Particularmente em sociedades nas quais as desconfianças nas leis e sua aplicação são acentuadas, a obediência pode resultar no medo da polícia, fazendo, por exemplo, com que os agentes policiais se sintam autorizados ao uso da coerção independentemente dos constrangimentos legais, como é recorrente na história da sociedade brasileira, mesmo após o processo de redemocratização.

Os resultados atuais da investigação dessa relevante questão estão indicando que a obediência às leis e a cooperação com as autoridades públicas variam significativamente nos diferentes padrões urbanos da cidade. Os moradores das áreas mais vulneráveis (Figura 3, padrões E, F e H) apresentam maior percepção da má conduta policial e relatam maior número de abordagens coercitivas feitas pelos agentes de segurança, revelam mais medo e confiam menos na polícia, o que ratifica a heterogeneidade intraurbana como uma variável essencial para avaliação da ação policial e seus efeitos. Conforme demonstra Zanetic et al. (2016) e Oliveira, Natal e Zanetic (2017), essa constatação leva ao desenvolvimento de estratégias sensíveis para mensuração de descobertas com essa natureza, promovendo avanço do conhecimento e aprimoramento metodológico cujos resultados possam informar e serem incorporados em políticas públicas de segurança e de promoção dos direitos humanos compatíveis com a sociedade democrática.

\section{[I] https://orcid.org/0000-0002-5358-1289}

Universidade de São Paulo, Faculdade de Filosofia Letras e Ciências Humanas, Departamento de Sociologia, Núcleo de Estudos da Violência. São Paulo, SP/Brasil.

Universidade de São Paulo, Instituto de Estudos Avançados, Programa USP Cidades Globais. São Paulo, SP/Brasil.

sadorno@usp.br

\section{[II] https://orcid.org/0000-0003-0299-8479}

Universidade de São Paulo, Faculdade de Filosofia Letras e Ciências Humanas, Núcleo de Estudos da Violência. São Paulo, SP/Brasil.

mbnery@gmail.com 


\section{Notas}

1) O crime de homicídio está previsto no art. 121 do Código Penal brasileiro.

2) Conforme Código Penal, art. 329 (Resistência), art. 23, incisos II e III (exclusão de ilicitude - legítima defesa e estrito cumprimento de dever legal).

3) Agressões e intervenção legal correspondem aos códigos X85-Y09 e Y35-36, respectivamente, conforme a 10ạ Revisão da Classificação Estatística Internacional de Doenças e Problemas Relacionados à Saúde (CID-10).

4) Estimativa apresentada no Relatório produzido pela Estratégia Nacional de Justiça e Segurança Pública (Enasp), em 2011 (FBSP, 2014).

5) A hipótese que norteia a argumentação de que o tribunal da facção criminosa PCC passou a mediar o uso da violência letal, com impacto no número de assassinatos, chacinas e demais formas de violação do direito à vida humana.

6) Também existia o sistema de dados do Ministério da Saúde, mas ele foi implementado gradualmente em todo o país, implicando diferença entre esse o sistema e o Registro Civil, o qual sempre apresentava um maior número de ocorrências.

7) A população anualizada intercensitária do estado de São Paulo, região metropolitana e município de São Paulo, entre 1980 e 2016, foi calculada tendo por base o percentual de crescimento indicado pela Projeção da População do Brasil do IBGE. A população de 1974 a 1979 foi calculada considerando-se os números dos censos de 1970 e 1980 e a evolução linear desses números.

8) Criado em 1924, pela lei n. 2304, o Deops foi um dos mais relevantes órgãos de controle social e repressão institucionalizada, empregado principalmente durante o Estado Novo e mais tarde no Regime Militar.

9) O Deplan foi um dos órgãos de apoio da Delegacia Geral de Polícia, incumbido de planejar, coordenar e controlar seus recursos humanos e materiais. Em 1999, com a edição do decreto n. 44.448, ele foi unido ao antigo Departamento de Planejamento e Controle da Polícia Civil (Deplan), surgindo o Departamento de Administração e Planejamento da Polícia Civil (DAP), órgão de apoio da Polícia Civil.

10) Oficializado em 14 de março de 1986, pelo decreto de n. 24.919, O DHPP é o órgão responsável pela investigação de crimes contra o patrimônio e em acidentes de trânsito, bem como contra a vida.

11) Corroborado pelos dados do Acervos de Dados em Segurança Pública - AdeSP. Disponível em: http://produtos.seade.gov.br/projetos/acervossp/. Acesso em: 9 ago 2018.

12) A partir de 1996, o agrupamento de causas de morte passa a se referir à $X$ Revisão da Classificação Internacional de Doenças. Dessa forma, comparações com informações apresentadas em anos anteriores devem ser feitas com ressalvas.

13) Diante da ausência/inconsistência das informações obtidas, os dados do registro civil/atestado de óbito da RMSP, no período 1996-2003, foram omitidos.

14) Disponível em: http://produtos.seade.gov.br/produtos/anuario/. Acesso em: 10 ago 2018.

15) Disponível em: http://produtos.seade.gov.br/produtos/mrc/index.php. Acesso em: 10 ago 2018. 
16) Vide nota 11.

17) Vide nota 12

18) Diante da ausência/inconsistência das informações obtidas, os dados do registro civil/atestado de óbito da RMSP, no período 1996-2003, foram gerados pelos autores tendo por base o número de ocorrências desses registros no estado de São Paulo e a proporção de homicídios registados pela polícia civil.

19) Vide nota 14.

20) Vide nota 15

21) Vide nota 7.

22) A mesma conclusão foi encontrada em Fundação Seade (2005) para os anos de 1997 a 2004.

23) Sobre a questão, ver Linebaugh (1983).

24) Implantado em 2002, Copom on-line, ou Sistema Informatizado de Administração Geoprocessada de Policiamento Ostensivo em Tempo Real, é sistema que agrega as informações geradas no atendimento e despacho do telefone190.

25) As densidades foram estimadas por Kernel e variam de 0 a 39 ocorrências em um raio de 1,5 km (cf. Nery, 2016).

26) Para visualização dos distritos e mais informações, sugerimos o acesso ao GeoSampa. Disponível em: <http://geosampa.prefeitura.sp.gov.br/PaginasPublicas/_SBC.aspx>. Acesso em: 9 ago 2018.

27) Na verdade, essa região não corresponde a uma área político-administrativa definida oficialmente; quando se referia a ela, genericamente, relacionava-a a um território que compreendia tanto o distrito do Jardim Ângela, em si, como grandes parcelas dos distritos fronteiriços (Capão Redondo, Jardim São Luís, Cidade Dutra e Parelheiros) e, até mesmo, do distrito de Campo Limpo.

28) Localidades como Jardim Souza, no Jardim Ângela; Jardim Sandra, no Capão Redondo; Jardim São Januário, em Campo Limpo; Parque São Miguel, no Grajaú; Jardim Ondina, em Brasilândia; e Jardim Ricardo, em São Mateus, servem de exemplos de bairros com baixa concentração de homicídios, tidos como muito violentos no ano de 1999.

29) Conforme Lima (2009).

30) Claro está que resultados obtidos mediante análises baseadas em dados e tratamento quantitativos requerem ainda estudos com metodologias qualitativas, de tipo etnográfico, que possam melhor descrever vivências urbanas, natureza dos conflitos locais, presença de instituições, intervenção das autoridades públicas, por exemplo.

31) Esse resultado foi encontrado em Peres et al. (2011), empregando dados sobre óbitos ocorridos no Município, coletados da base de dados do Programa de Aprimoramento das Informações sobre Mortalidade, seguindo a CID-10. Uma análise semelhante foi feita para este artigo com dados sobre homicídios dolosos, obtidos no Infocrim, seguindo o código penal brasileiro, e o mesmo resultado foi obtido.

32) Vide nota 25. 
33) "Mortos por terceiros" é a soma do número de pessoas mortas em confronto com as polícias, civil e militar, e de homicídios dolosos. A partir de 2006, o total de pessoas mortas pela polícia civil correspondia, em média, a um ponto percentual dos valores do gráfico.

34) Fapesp Processo n. 2013/07923-7.

35) Procedimentos metodológicos foram realizados para validar a estratificação em padrões urbanos e as áreas-chave. Mais recentemente, em parceria com o IEA-USP (projeto Cidades Globais), as características e as diferenças relacionadas aos padrões urbanos foram novamente validadas por meio da aplicação da teoria de redes, para compreensão da importância das variáveis selecionadas para a definição dos padrões como componentes dos sistemas intraurbanos. Além disso, em parceria com o CeMEAI (Centro de Ciências Matemáticas Aplicadas a Indústria, CepidFapesp-USP), os mesmos padrões urbanos servem como fundamento para o desenvolvimento de um sistema computacional que, por meio de mapas e representações gráficas (wavelets), permite descrever a variabilidade, a inconsistência de fluxos, os picos sazonais e a complexidade de eventos de interesse, criminais e educacionais na cidade de São Paulo.

36) Os padrões urbanos são: comercial e de serviços (A); residencial de urbanização consolidada (B); urbanização radial (C); residencial disperso de urbanização radial (D); habitação irregular em áreas de urbanização antiga (E); residencial concentrado de urbanização gradativa em áreas de proteção aos mananciais e de risco geológico (F); habitação irregular concentrada em áreas de urbanização recente $(\mathrm{G})$; habitação em áreas periurbanas $(\mathrm{H})$.

\section{Referências}

ADORNO, S. (1994). "Cidadania e administração da justiça criminal”. In: DINIZ, E.; LEITE LOPES, S. e PRANDI, R. (orgs.). Anuário de Antropologia, Política e Sociologia. São Paulo, Anpocs/Ipea/ Hucitec, pp. 304-327.

(2002). Exclusão socioeconômica e violência urbana. Sociologias, v. 4, n. 8.

ADORNO, S.; DIAS, C. N. e NERY, M. B. (2016). “A cidade e a dinâmica da violência”. In: KOWARICK, L. Pluralidade Urbana em São Paulo. Editora 34.

ADORNO, S. e PASINATO, W. (2010). Violência e impunidade penal: da criminalidade detectada à criminalidade investigada. Dilemas: Revista de Estudos de Conflito e Controle Social. Rio de Janeiro, v. 3, n. 7, pp. 51-84.

ALVES, H. P. F. (2006). Vulnerabilidade socioambiental na metrópole paulistana: uma análise sociodemográfica das situações de sobreposição espacial de problemas e riscos sociais e ambientais. Revista Brasileira de Estudos de População, v. 23, n. 1, pp. 43-59.

BIDERMAN, C. et al. (2014). Pax monopolista and crime: the case of the emergence of the Primeiro Comando da Capital in São Paulo. CAF - Documento de trabajo n. 2014/2003. Disponível em: <http://www.scioteca.caf.com/handle/123456789/712/>. Acesso em: 9 ago 2018.

CALDEIRA, T. P. do R. (2000). Cidade de muros: crime, segregação e cidadania em São Paulo. São Paulo, Editora 34. 
CARDIA, N. e SCHIFFER, N. (2000). Violência e desigualdade social. Ciência e Cultura, v. 54, n. 1, pp. 25-31.

DIAS, C. N. (2013). PCC: Hegemonia nas prisões e monopólio da violência. São Paulo, Saraiva.

FAUSTO, B. (1984). Crime e cotidiano: a criminalidade em São Paulo, 1880-1924. São Paulo, Edusp.

FBSP - Fórum Brasileiro de Segurança Pública. (2014). Anuário brasileiro de segurança pública. (2016). Anuário brasileiro de segurança pública. (2017). Anuário brasileiro de segurança pública. (2018). Anuário brasileiro de segurança pública.

FELTRAN, G. S. (2011). Fronteiras de tensão: política e violência nas periferias de São Paulo. São Paulo, Unesp.

(2012). Governo que produz crime, crime que produz governo: o dispositivo de gestão do homicídio em São Paulo (1992-2011). Revista Brasileira de Segurança Pública, v. 6, pp. 232-255. (2018). Irmãos, uma história do PCC. São Paulo, Companhia das Letras.

FUNDAÇÃO SEADE (2005). Mortes por atos violentos em São Paulo: a importância de informações complementares. SP Demográfico. São Paulo, ano 6, n. 3.

GURR, T. R. (ed). (1989). Violence in America. Newbury Park, Sage Publications Inc., 2v.

LIMA, R. S. (2008). A produção da opacidade: estatísticas criminais e segurança pública no Brasil. Novos Estudos - Cebrap. São Paulo, n. 80, pp. 65-69.

(2009). Criminalidade violenta e homicídios em São Paulo: fatores explicativos e movimentos recentes. In: SEMINÁRIO CRIME, VIOLÊNCIA E CIDADE. Paper. São Paulo, Universidade de São Paulo, Programa de Pós-Graduação em Sociologia-USP e NEV.

LIMA, J. M. M. (2011). Democracia e accountability: violência policial e práticas de controle sobre a Polícia Militar do estado de São Paulo. Dissertação de mestrado. São Paulo, Universidade Estadual Paulista.

LINEBAUGH, P. (1983). “Crime e industrialização: a Grã-Bretanha no século XVIII”. In: PINHEIRO, P. S. (org.). Crime, violência e poder. São Paulo, Brasiliense, pp. 99-137.

MANSO, B. e DIAS, C. (2018). A Guerra. A ascensão do PCC e o mundo do crime no Brasil. São Paulo, Todavia.

MELLO JORGE, M. H. P. (1981). Mortalidade por causas violentas no município de São Paulo. Mortes intencionais. Revista de Saúde Pública. São Paulo, v. 15, n. 2, pp. 165-193.

MINAYO, M. C. S. (1994). Violência social sob a perspectiva da saúde pública. Cad. Saúde Pública [online], v. 10, suppl. 1, pp. S7-S18.

MISSE, M. (org.). (2010). O inquérito policial no Brasil: uma pesquisa empírica. Rio de Janeiro, Fenapef/ Necvu/Booklink.

MUCCHIELLI, L. (1998). La découverte du social. Naissance de la sociologia en France. Paris, Éditions de la Découverte.

NERY, M. B. (2006). Gestão urbana: sistemas de informação geográfica e o estudo da criminalidade no município de São Paulo. Dissertação de Mestrado. São José dos Campos/SP, Instituto Nacional de Pesquisas Espaciais, Ministério da Ciência e Tecnologia. 
NERY, M. B. (2012). Mortalidade por atos violentos em São Paulo: ponderações necessárias. 5o Relatório Nacional sobre os Direitos Humanos no Brasil, pp. 66-71.

(2016). Crime e violência no cenário paulistano: o movimento e as condicionantes dos homicídios dolosos sob um recorte espaço-temporal. Tese de Doutorado. São Paulo, Universidade de São Paulo.

NERY, M. B. et al. (2012). Regimes espaciais: dinâmica dos homicídios dolosos na cidade de São Paulo entre 2000 e 2008. Revista de Panamericana de Salud Publica. Washington, DC, v. 32, n. 6, pp. 405-412.

(2014). Homicídios dolosos na cidade de São Paulo: fatores associados à queda entre 2000 e 2010. Revista Brasileira de Segurança Pública, São Paulo, v. 8, n. 2, pp. 32-47.

(2015). A delimitação de áreas-chave para estudos longitudinais em São Paulo (SP), Brasil. Relatório interno (versão 2). São Paulo, Núcleo de Estudos da Violência, USP.

OLIVEIRA, T.; NATAL, A. e ZANETIC, A. (2017). Preditores e impactos da legitimidade policial: testando a teoria da justeza procedimental em São Paulo. 18 CONGRESSO BRASILEIRO DE SOCIOLOGIA. Brasília.

PERES, M. F. T. et al. (2008). Homicídios, desenvolvimento socioeconômico e violência policial no Município de São Paulo, Brasil. Revista Panamericana de Salud Publica, v. 23, pp. 268-276.

(2011). Queda dos homicídios em São Paulo, Brasil: uma análise descritiva. Revista de Panamenicana de Salud Publica. Washington, DC, v. 29, n. 1, pp. 17-26.

PEZZIN, L. E. e MACEDO, R. B. M. (1987). Criminalidade urbana e crise econômica: o caso de São Paulo. São Paulo, IPE/USP.

PORTO, M. S.G. (2001). "Violência e segurança: a morte como poder?” In: OLIVEIRA, D. D. et al. (orgs.). Violência policial: tolerância zero? Goiânia, Editora da UFG, pp. 29-51.

SOUSA, C. A. M; SILVA, C. M. F. P. e SOUZA, E. R. (2018). O efeito do contexto sobre a incidência de homicídios: existem evidências suficientes? Interface - Comunicação, Saúde, Educação, v. 22, n. 66, pp. 915-927.

TOBIAS, J. J. (1967). Crime and industrial society in the 19th Century. Londres, Stocken Books.

WAISELFISZ, J. J. (2007). Mapa das mortes por violência. Estudos Avançados. São Paulo, v. 21, n. 61, pp. 119-138.

ZALUAR, A. (1999). Um debate disperso: violência e crime no Brasil da redemocratização. São Paulo em Perspectiva. São Paulo, v. 13, n. 3, pp. 3-17.

(2004). Integração perversa: pobreza e tráfico de drogas. São Paulo, FGV Editora.

ZANETIC, A. et al. (2016). Legitimidade da polícia: segurança pública para além da dissuasão. Civitas Revista de Ciências Sociais, v. 16, n. 4, pp. 148-173.

Texto recebido em 3/out/2018

Texto aprovado em 10/dez/2018 